\title{
Review
}

\section{Cerebrospinal Fluid Biomarkers for Early and Differential Alzheimer's Disease Diagnosis}

\author{
Maria Bjerke ${ }^{\mathrm{a}, *}$ and Sebastiaan Engelborghs ${ }^{\mathrm{a}, \mathrm{b}}$ \\ ${ }^{a}$ Reference Center for Biological Markers of Dementia (BIODEM), Institute Born-Bunge, \\ University of Antwerp, Antwerp, Belgium \\ ${ }^{\mathrm{b}}$ Department of Neurology and Memory Clinic, Hospital Network Antwerp (ZNA) Middelheim \\ and Hoge Beuken, Antwerp, Belgium
}

Accepted 19 December 2017

\begin{abstract}
An accurate and early diagnosis of Alzheimer's disease (AD) is important to select optimal patient care and is critical in current clinical trials targeting core AD neuropathological features. The past decades, much progress has been made in the development and validation of cerebrospinal fluid (CSF) biomarkers for the biochemical diagnosis of $\mathrm{AD}$, including standardization and harmonization of (pre-) analytical procedures. This has resulted in three core CSF biomarkers for AD diagnostics, namely the 42 amino acid long amyloid-beta peptide $\left(\mathrm{A} \beta_{1-42}\right)$, total tau protein (T-tau), and tau phosphorylated at threonine $181\left(\mathrm{P}-\mathrm{tau}_{181}\right)$. These biomarkers have been incorporated into research diagnostic criteria for $\mathrm{AD}$ and have an added value in the (differential) diagnosis of $\mathrm{AD}$ and related disorders, including mixed pathologies, atypical presentations, and in case of ambiguous clinical dementia diagnoses. The implementation of the CSF $A \beta_{1-42} / A \beta_{1-40}$ ratio in the core biomarker panel will improve the biomarker analytical variability, and will also improve early and differential AD diagnosis through a more accurate reflection of pathology. Numerous biomarkers are being investigated for their added value to the core $\mathrm{AD}$ biomarkers, aiming at the $\mathrm{AD}$ core pathological features like the amyloid mismetabolism, tau pathology, or synaptic or neuronal degeneration. Others aim at non-AD neurodegenerative, vascular or inflammatory hallmarks. Biomarkers are essential for an accurate identification of preclinical $\mathrm{AD}$ in the context of clinical trials with potentially disease-modifying drugs. Therefore, a biomarker-based early diagnosis of $\mathrm{AD}$ offers great opportunities for preventive treatment development in the near future.
\end{abstract}

Keywords: Alzheimer's disease, amyloid, biomarkers, cerebrospinal fluid, dementia, diagnosis, mild cognitive impairment, neuropathology, tau

\section{INTRODUCTION}

An accurate and early diagnosis of Alzheimer's disease (AD) is important to select the optimal patient care and is critical in current clinical trials targeting

\footnotetext{
${ }^{*}$ Correspondence to: Prof. Dr. Maria Bjerke, Reference Center for Biological Markers of Dementia (BIODEM), University of Antwerp, Universiteitsplein 1, BE-2610 Antwerp, Belgium. Tel.: +323 26523 94; E-mail: maria.bjerke@uantwerpen.be.
}

core AD neuropathological features. Its value will grow even more so when a disease modifying treatment is available. To date, diagnosis of AD is still based on a full clinical work-up, including neuropsychological testing [1] and brain imaging such as magnetic resonance imaging (MRI). However, clinical dementia diagnosis does not always correspond to the neuropathological definite diagnosis with clinical diagnostic accuracy levels ranging between $82 \%$ and 
$84 \%[2,3]$. When a clinician should discriminate AD from a non-AD dementia relying on (non-biomarker based) clinical diagnostic criteria, $16 \%$ are misdiagnosed and $16 \%$ of the patients have a doubtful AD versus non-AD diagnosis $[2,4,5]$. Therefore, it is important to increase the clinical diagnostic accuracy, which will even be harder at an early stage of the disease. Since biochemical changes are believed to take place and be detectable through biomarkers around two decades before clinical symptom onset [6], they will be important tools in the clinical setup for early and differential diagnosis of AD.

Several attempts have been made to counteract the effects of amyloid- $\beta(A \beta)$ mismetabolism, which is assumed to be one of the key pathogenic events in AD. However, all but one clinical trials have failed to reverse or slow down cognitive decline [7]. Possible reasons for the failures may be that non-homogeneous groups of patients have been included in the trials, the treatment has been administered too late in the course of the disease or has been too short, and/or that the $\mathrm{A} \beta$ aggregation is not the key event in $\mathrm{AD}$.

Also driven by the need of clinical trials to select 'pure' AD subjects early in the course of the disease, much effort has been put in developing biomarkers for $\mathrm{AD}$ during the past two decades (see Alzforum biomarker database and meta-analyses at http://www.alzforum.org/alzbiomarker) [8]. This has resulted in three core cerebrospinal fluid (CSF) biomarkers for $\mathrm{AD}$ diagnostics, namely the 42 amino acid long amyloid-beta peptide $\left(A \beta_{1-42}\right)$, total tau protein (T-tau), and tau phosphorylated at threonine $181\left(\mathrm{P}-\operatorname{tau}_{181}\right)$ [9]. A biomarker classification scheme, which is based on the early findings and interpretations of the above CSF biomarkers by Blennow et al. [10], has been suggested as a tool to assess the pathophysiology in the brain independent of the clinical evaluation. This so called " $\mathrm{A} / \mathrm{T} / \mathrm{N}$ " system, captures the three main neuropathological findings related to $\mathrm{AD}$. The A refers to the $\mathrm{A} \beta$ pathology measured by either amyloid PET or CSF $A \beta_{1-42}$, $\mathrm{T}$ represents tangle pathology and is assessed by either tau PET or CSF P-tau, and N stands for neurodegeneration or neuronal injury detected by either [18F]-fluorodeoxyglucose-PET, structural MRI, or CSF T-tau [11].

Biomarkers have been incorporated into research diagnostic criteria for $\mathrm{AD}$ [12-14] and, although the clinical examination (including full neuropsychological evaluation) is still the basis for AD diagnosis [1], these biomarkers are being introduced in daily clinical practice as in vivo surrogate markers for the confirmation of $\mathrm{AD}$ neuropathology. The core CSF $\mathrm{AD}$ biomarkers increase the diagnostic accuracy for diagnosing $\mathrm{AD}$ (mainly in cases with atypical presentations), also in its prodromal phase (mild cognitive impairment (MCI) due to AD) $[15,16]$ and are able to differentiate between $\mathrm{AD}$ and psychiatric disorders [17]. The CSF biomarkers are useful to diagnose AD in patients with ambiguous clinical dementia diagnoses [4] and in cases with mixed brain pathology like AD with cerebrovascular disease [5, 18, 19].

During ten years of CSF AD biomarker analyses, the number of samples referred to the BIODEM lab at UAntwerp from clinical centers has increased with $238 \%$ [20]. Due to the revisions of diagnostic criteria for $\mathrm{AD}$ diagnosis and the herein described use of CSF biomarkers [12-14], confidence in the importance of biomarkers has grown. Not only are they used more often by clinicians, they are also useful in clinical trials as enrichment strategy or outcome measures due to their in vivo pathophysiological characteristics [21]. However, there is a general shift from samples referred for neurochemical confirmation of $\mathrm{AD}$ diagnosis to referrals for differential $\mathrm{AD}$ versus non-AD dementia diagnosis. This may be due to the growing scientific support for biomarkerbased differential diagnosis between $\mathrm{AD}$ and non-AD dementias [22], also in the prodromal phase [23].

\section{BIOMARKER ASSOCIATION WITH NEUROPATHOLOGY AND DETECTION OF DEFINITE AND CLINICAL AD}

A biomarker should be readily accessible, accurately indicating a biological or pathological state and preferably inexpensive. In case of neurodegenerative biomarkers, the choice of CSF over blood biomarkers, at least in the case of $A \beta_{1-42}$, is mainly based on the fact that the central nervous system is secluded from the systemic circulation, which precludes direct translation of biomarker findings of the brain to the periphery. This has been supported by studies in plasma showing conflicting results, and in the case of $A \beta_{1-42}$ for instance no overall difference between $\mathrm{AD}$ and controls were found in a meta-analysis [8] (http://www.alzforum.org/alzbiomarker). Furthermore, no correlation between plasma and CSF levels of the $A \beta_{1-42}$ biomarker has been found $[24,25]$. Tau on the other hand have shown more potential as a plasma or serum biomarker for the differentiation between $\mathrm{AD}$ and controls [8] (http://www.alzforum.org/alzbiomarker); 
however, speaking against a direct translation of CSF values into plasma is the finding that nor tau CSF levels correlate with its plasma counterpart [26]. Nevertheless in CSF, $A \beta_{1-42}$, T-tau, and P-tau 181 have shown to be consistently altered in AD versus controls, also in the prodromal phase [8] (http://www.alzforum.org/alzbiomarker).

The BIODEM lab was the first to demonstrate the diagnostic value of the CSF biomarkers $A \beta_{1-42}$, T-tau, and P-tau 181 in clinical AD using the neuropathological diagnosis as a reference $[2,27]$. The study demonstrated that all three biomarkers provide useful information, showing promising sensitivity and specificity values that systematically exceed the $80 \%$ threshold. The use of a biomarker-based model in patients with a clinically ambiguous diagnosis, resulted in a correct diagnosis in the majority of autopsy-confirmed AD and non-AD cases, indicating that biomarkers have an added diagnostic value in these cases [1, 2, 4].

Moreover, $A \beta_{1-42}$ has proven its potential to mirror the build-up of plaques, which is supported by the inverse correlation between the CSF A $\beta_{1-42}$ levels and the amount of amyloid plaques found at neuropathological examination of AD brains [28] as well as the in vivo association with cortical amyloid load as measured by amyloid PET in patients with AD [29-31]. The present core AD CSF biomarkers, including $A \beta_{1-42}$, T-tau, and P-tau 181 , have recently been incorporated into the research diagnostic criteria of $\mathrm{AD}$, with a CSF profile suggestive for $\mathrm{AD}$ being low $A \beta_{1-42}$ in combination with high T-tau and/or P-tau 181 levels [14].

\section{THE ADDED VALUE OF CSF BIOMARKERS FOR EARLY AND DIFFERENTIAL AD DIAGNOSIS}

It should be emphasized that biomarkers are especially important for the selection of preclinical AD subjects (who are asymptomatic at risk for AD or subjects who suffer from subjective cognitive decline [SCD] due to AD) and for the selection of patients in the earliest symptomatic stages of $\mathrm{AD}$ (prodromal AD or MCI due to AD). SCD and MCI are both very heterogeneous syndromes and when assessed in a large clinical cohort less than $25 \%$ of the subjects converted to dementia after an extensive follow-up period of 6 years. The majority of these SCD and MCI subjects (42\%) developed dementia due to $\mathrm{AD}$, while subjects with mixed $\mathrm{AD}$ with cerebrovascular disease and pure vascular dementia $(\mathrm{VaD})$ were the second most common diagnoses representing about a quarter each of the converters [32]. In this particular setting, CSF $A \beta_{1-42}$ would portrait as a very attractive biomarker for early AD detection since both CSF T-tau and P-tau 181 alterations seem to occur at a later time point in the disease process closer to clinically detectable dementia [33]. However, it has previously been suggested and shown that a combination of the core AD biomarkers is superior compared with the single biomarkers alone, especially for differential diagnosis [2]. Investigating autopsy-confirmed AD and non-AD dementia patients has also improved our knowledge and insights with regard to the differential diagnostic value of the existing AD CSF biomarkers. An added discriminatory value for $\mathrm{AD}$ versus non-AD dementia was shown for P-tau 181 to the panel of $A \beta_{1-42}$ and T-tau $[34,35]$ and, furthermore, that the ratio of $A \beta_{1-42} / \mathrm{P}-\operatorname{tau}_{181}$ has shown a higher diagnostic accuracy than $A \beta_{1-42}$, T-tau, and P-tau 181 alone, but also than the $A \beta_{1-42} / \mathrm{T}$-tau ratio to discriminate between $\mathrm{AD}$ and non-AD dementias. This clearly shows the importance of P-tau 181 in the biomarker panel for differential dementia diagnosis $[2,4,20,35]$.

Although there is strong evidence for the importance of CSF $A \beta_{1-42}$ as a biomarker for early $A D$ detection, there are still limitations to be overcome. One such limitation is the overlap of CSF $A \beta_{1-42}$ between different neurodegenerative disorders. For instance, decreased CSF levels of $A \beta_{1-42}$ have also been observed in patients with prodromal and manifest (subcortical) $\mathrm{VaD}[34,36,37]$, dementia with Lewy bodies (DLB) [34, 38], Creutzfeldt-Jakob disease (CJD) [34, 39], and frontotemporal lobar degeneration (FTLD) [34, 40] compared with healthy individuals. Though the $A \beta_{1-42}$ levels are most often still lower in AD compared with $\mathrm{VaD}$ and DLB, a significant overlap nevertheless limits the discrimination. Concomitant AD pathology in DLB has been shown to occur in $72 \%$ of autopsy-confirmed DLB patients, which was reflected by low CSF $A \beta_{1-42}$ values [38]. While AD pathology is often found in combination with both DLB and cerebrovascular disease [2, 38], decreased $A \beta_{1-42}$ levels in CSF of patients with pure $\mathrm{VaD}$ (related to subcortical small vessel disease), CJD or FTLD may on the other hand be related to other pathophysiological characteristics than plaque burden.

The introduction of $\mathrm{A} \beta$ peptide ratios was proposed already in the late 1990s to improve the AD differential diagnosis [41, 42]. It has previously been 
shown that CSF $A \beta_{1-42}$ and florbetapir-PET showed a nonlinear association with pathological values of CSF $A \beta_{1-42}$ preceding PET abnormalities [29] and it has been suggested that CSF $A \beta_{1-42}$ is an earlier marker of brain amyloid pathology compared with PET [43]. However, this has more or less been disputed by the finding that the CSF $A \beta_{1-42} / A \beta_{1-40}$ ratio shows a higher concordance with amyloid load in the brain as assessed by PET compared with $\mathrm{A} \beta_{1-42}$ alone [31, 44, 45]. The $\mathrm{A} \beta_{1-42} / \mathrm{A} \beta_{1-40}$ ratio is decreased in $\mathrm{AD}$ and more accurately differentiates between $\mathrm{AD}$ and controls, FTLD, VaD, and DLB, due to the latter four groups having ratios that approach control levels because of decreased concentrations in both $A \beta_{1-42}$ and $A \beta_{1-40}$. This finding supports the increased association of the CSF $\mathrm{A} \beta_{1-42} / \mathrm{A} \beta_{1-40}$ ratio to pathology as the above nonAD dementias are not affected by plaque pathology in their purest forms [44]. Furthermore, the ratio shows a high concordance with PET, also in subjects with subjective cognitive decline and mild cognitive impairment (AUC $\geq 0.93$ ), indicating a high agreement at the early stages of disease [46]. However, more comparative studies are needed to investigate the biomarker characteristics for early pre-clinical detection of amyloid pathology with regard to the timing of CSF $A \beta_{1-42} / A \beta_{1-40}$ ratio and amyloid PET. The $A \beta_{1-42} / A \beta_{1-40}$ ratio has also been shown to perform equally well as the combination of $A \beta_{1-42}$, P-tau 181 , and T-tau in differentiating between AD and other non-AD dementias [47]. In another study, it was shown that adding the $A \beta$ ratio to the core biomarkers improved the accuracy when distinguishing between definite $\mathrm{AD}$ and non-AD dementias in cases with intermediate $\mathrm{P}-\mathrm{tau}_{181}$ [48], indicating its potential usefulness as a biomarker for differential dementia diagnosis. Along the same line, the added value to the core biomarkers has also been assessed in a clinical setting where it was shown that in cases with a discrepancy in the AD core biomarker profile, the $A \beta_{1-42} / A \beta_{1-40}$ ratio was in agreement with the clinical diagnosis in over $50 \%$ of the cases [49]. All together, these findings speak in favor of the added value of the $A \beta_{1-42} / A \beta_{1-40}$ ratio for differential diagnosis, when alterations in CSF tau are yet to be seen. Other ratios that have been less well investigated but still show potential as biomarkers are $A \beta_{1-42} / A \beta_{1-38}$ and $A \beta_{1-42} / A \beta_{1-37}$ [35]. In this study, it was concluded that $A \beta_{1-42} / A \beta_{1-38}$ ratio performed the best for the separation between $\mathrm{AD}$ and $\mathrm{DLB}$, and that it outperformed the single $\mathrm{AD}$ biomarkers. Also, $A \beta_{1-42} / \mathrm{A} \beta_{1-37}$ was shown to have an added value for the differentiation between $\mathrm{AD}$ and FTLD [35]. More studies are needed in order to determine which $\mathrm{A} \beta$ peptide ratios achieve the best separation in different diagnostic settings.

The CSF $A \beta_{1-42} / A \beta_{1-40}$ ratio has been shown to be superior to $A \beta_{1-42}$ alone when concerned with the distinction between MCI patients who progress to $A D$ dementia and MCI patients who remain stable [50]. The early diagnostic value of the existing biomarker panel might be improved by the addition of $A \beta_{1-40}$, since formation of amyloid-plaques is believed to be initiated up to twenty years before the onset of the clinical symptoms. The use of low CSF $A \beta_{1-42}$ and the CSF $A \beta_{1-42} / A \beta_{1-40}$ ratio opens new possibilities for the accurate identification of 'asymptomatic at risk for AD' subjects for clinical trials.

\section{NEW AD AND NON-AD RELATED BIOMARKERS FOR IMPROVED DIFFERENTIAL DIAGNOSIS}

Numerous biomarkers have been investigated for their added value to the core AD biomarkers in early detection or differential diagnosis of AD. Several of those have aimed at the AD core pathological features like the amyloid mismetabolism, tau pathology, or synaptic or neuronal degeneration. Others have aimed at non-AD neurodegenerative, vascular, or inflammatory hallmarks.

More or less overlapping results have been found for the differentiation of $\mathrm{AD}$ and non-AD dementias including DLB, FTLD, and VaD using the core AD biomarkers $A \beta_{1-42}$, T-tau, and P-tau 181 . When concerned with FTLD-tau, tau CSF levels are usually intermediate ranging from normal to abnormal, precluding its usability as a biomarker for differential diagnosis [51]. Other tau species, with for instance different modifications, may be more specific for either AD or FTLD-tau pathology increasing its clinical utility. Based on this thought, an assay measuring non-phosphorylated tau at positions T175 and T181 was developed, which was highly accurate at detecting $\mathrm{MCI}$ due to $\mathrm{AD}$ when compared to healthy controls [52]. However, there was no added value compared with the core AD biomarkers for the differential diagnosis of $\mathrm{AD}$ with regard to non-AD neurodegenerative diseases, including FTLD and DLB. Neither was there any added value for the differentiation of AD or FTLD from healthy controls [40]. 
Other core $\mathrm{AD}$ biomarker than $\mathrm{A} \beta_{1-42}$ representing $A \beta$ or amyloid- $\beta$ protein precursor (A $\beta P P)$ metabolism have also been investigated for their ability to discriminate $\mathrm{AD}$ from healthy controls, such as $A \beta_{1-40}$ and $A \beta_{1-38}$ peptides as well as soluble $\mathrm{A} \beta \mathrm{PP} \alpha$ and $\beta$ protein fragments. They have shown to be unaltered in $\mathrm{AD}[8,53,54]$, but decreased levels have been associated with inflammation, cerebrovascular disease, and white matter lesions $[54,55]$. As mentioned before, the $C S F A \beta_{1-42} / A \beta_{1-40}$ ratio is likely to perform with a higher specificity than for instance $A \beta_{1-42} / \mathrm{P}-\operatorname{tau}_{181}$ to discriminate between $\mathrm{AD}$ and $\mathrm{VaD}[56]$ as well as FTLD and DLB [35]. These findings are of outermost importance for the accuracy of detection of amyloid plaque pathology that characterizes $\mathrm{AD}$, both for clinical practice as well as for patient inclusion into clinical trials. Furthermore, these biomarkers may contribute to detect cerebrovascular disease that may also affect the trajectory of AD under the influence of mixed pathology.

As synaptic and neuronal degeneration is assumed to correlate with cognitive decline in $\mathrm{AD}$, being able to monitor neurodegeneration through synaptic function would be an important advantage, both clinically and in clinical trials to detect disease progression or treatment efficacy. For this purpose, the postsynaptic protein neurogranin has been investigated and was found to be increased in CSF of patients with MCI and dementia due to AD as compared with healthy controls [26, 57], while in paired plasma samples no difference was found [26]. As CSF neurogranin and tau has been found to correlate strongly, its added value to the core biomarkers needs further attention as well as the relation to clinical parameters [26, 57].

Neurofilament light (Nf-L) is another marker of neuronal integrity reflecting axonal damage of the subcortical white matter. Nf-L is therefore considered as a candidate biomarker for subcortical small vessel disease and related dementia [58-60] as it has been found to be associated with white matter hyperintensities [55, 61]. Nf-L has been found to be elevated in CSF from patients with subcortical $\mathrm{VaD}$ and mixed $\mathrm{AD}$ with subcortical small vessel disease as well as in FTLD [36, 37, 62]. However, it has also been proposed as a biomarker for $\mathrm{AD}$ [8], if Nf-L in this case is related to concomitant cerebrovascular disease remains to be clarified. The relation to cerebrovascular disease has also been corroborated by findings of increased levels in stroke [63]. So far, Nf-L is the only marker that has been shown to be directly transferrable from CSF to plasma and show potential as a clinical tool to predict cognitive decline and brain atrophy in $\mathrm{AD}$ [64]. Another marker reflecting axonal damage or remodeling of the myelin sheet is myelin basic protein (MBP), which has also been found to be increased in subcortical $\mathrm{VaD}$ and stroke [37, 63] and associated with white matter lesions [55]. If MBP more specifically reflects white matter lesions related to subcortical $\mathrm{VaD}$ than $\mathrm{Nf}-\mathrm{L}$ remains to be shown.

Other markers that have been proposed to improve the differential diagnosis between $\mathrm{AD}$ and (subcortical) $\mathrm{VaD}$ are biomarkers reflecting blood-brain barrier (BBB) dysfunction, such as albumin ratio, and markers related to inflammation and opening of the BBB $[58,59]$. The albumin ratio has consistently been found to be increased in subcortical $\mathrm{VaD}$ compared with $\mathrm{AD}$ and healthy controls [36, 37, 62]. Moreover, matrix metalloproteinases (MMP9) known to be associated with BBB opening has been found to be increased in subcortical $\mathrm{VaD}$ together with its endogenous inhibitor, the tissue inhibitor of metalloproteinases 1 (TIMP-1) compared with AD and healthy controls [37]. TIMP-1 has also been shown to correlate with white matter lesion volume and albumin ratio, while MMP-9 has been shown to be associated with white matter lesion progression $[37,55]$. These markers and other markers related to inflammation and cerebrovascular disease needs further attention for their role to reflect subcortical small vessel disease [60].

Major molecular pathologies underlying FTLD include aggregation of transactive response DNAbinding protein of $43 \mathrm{kDa}$ (TDP-43, FTLD-TDP), and tau (FTLD-tau) [65]. Having the potential to be a specific biomarker for FTLD-TDP, a lot of research was done on TDP-43. Because of low absolute levels, quantitative analysis of TDP-43 in biofluids will require a very sensitive immunoassay, preferably specific for pathological TDP-43 [66]. So far, research has not been translated into a sensitive and specific biomarker for TDP-43. The only FTLD-specific biomarker is progranulin, showing decreased concentrations in serum or plasma of subjects with GRN mutation-related FTLD (a subgroup of FTLD-TDP) $[67,68]$. The diagnostic value of CSF progranulin levels is a matter of debate.

The discovery of $\alpha$-synuclein ( $\alpha$-syn) as a major component of Lewy bodies, which is the neuropathological hallmark of Parkinson's disease (PD) and DLB, initiated research on $\alpha$-syn as a potential CSF biomarker. $\alpha$-syn is as well a constituent of glial inclusions in multiple system atrophy (MSA). Large variations in the absolute levels of $\alpha$-syn in CSF and serum have bene revealed, even when the same 
types of $\alpha$-syn isoforms were detected [69]. Differences in values are related to differences in analytical procedures, stressing the need for standardization of procedures [70]. CSF $\alpha$-syn levels are decreased in PD and DLB but also in MSA [69] as compared to $\mathrm{AD}$ where increased levels have been reported, correlating with tau and thus possibly with neurodegeneration [71]. These data show the (differential) diagnostic potential of $\alpha$-syn as a biomarker.

Fast progressive AD phenotypes often pose a diagnostic challenge and may be confused clinically with CJD. The major biological diagnostic biomarker for identifying CJD, 14-3-3 protein in CSF, unfortunately lacks specificity when confronted with a rapid dementia presentation $[72,73]$. Very high T-tau concentrations may be found in AD in CSF ( $>1200$ $\mathrm{pg} / \mathrm{ml}$ ), but are also indicative of CJD. In case of suspicion of CJD, analysis of the total concentration of prion protein (t-PrP) in CSF has been shown to be useful to increase the diagnostic accuracy [39]. The use of CSF t-PrP levels may be beneficial in clinical practice in addition to the current classic biomarkers.

\section{IMPROVEMENT AND HARMONIZATION OF AD CSF BIOMARKER MEASUREMENTS}

Even with an elevated confidence in the use of CSF biomarkers for the clinical work-up of dementia diagnosis, multicenter trials have shown that there is a substantial center-to-center variation [9].

Due to its favorable diagnostic characteristics and the relative inexpensive costs, much effort has been put into making $A \beta_{1-42}$ manageable as an $A D$ biomarker worldwide to be used in daily clinical dementia practice as in vivo surrogate marker for plaque pathology [20]. Though the absolute measurements of $A \beta_{1-42}$ in CSF show inter-laboratory variability, mainly due to differences in pre-analytical and analytical procedures, which also includes the performance of different assays utilizing different calibrators. This causes an important concern as direct comparisons of measurements between laboratories and across techniques are not reliable, hampering biomarker development and their utility for clinical routine diagnosis. Storage in different tubes, different aliquot volumes, and number of freeze-thaw cycles are factors that significantly influence CSF biomarker concentrations, stressing the need for standard operating procedures for preanalytical sample handling [74-76]. However, it has previously been suggested [77] and verified by us that the $A \beta_{1-42} / A \beta_{1-40}$ ratio is a more robust measurement compared with $A \beta_{1-42}$ alone as it corrects for intra-individual confounding factors and minimizes variability due to for instance adsorption of $\mathrm{A} \beta$ peptides to storage tubes [76]. An exploratory study in MCI patients, on the other hand, with clinical follow-up and autopsy-confirmed AD patients provided evidence that, for a specific context of use, the impact on clinical diagnostic accuracy of biomarker concentration shifts might be lower than originally expected [78]. However, standardization of (pre)analytical sample handling as well as the cut-off thresholds should be accomplished as they influence biomarker results [74-76, 79].

Major efforts are undertaken to overcome these problems by introducing a certified reference material and a certified reference method that can be used for value assignment of the assay calibrators [79-81]. Also, the Alzheimer's Association external quality control (QC) program monitors site-to-site and batchto-batch CSF measurement variability for the purpose of enabling the participating laboratories to synchronize their procedures [82]. These efforts will lead to precise and reliable measurements between laboratories that will enable the introduction of a worldwide cut-off point for CSF A $\beta_{1-42}$, T-tau and P-tau 181 measurements for the purpose of clinical diagnostics and patient stratification in clinical trials.

With this in mind, several programs for standardization and harmonization were set up, such as the QC program of the Alzheimer's Association, as well as the Alzheimer Biomarker Standardization Initiative (ABSI) and the JPND BIOMARKAPD consortium [79, 82-84].

\section{CONCLUDING REMARKS}

Over the past decades, much progress has been made in the development and validation of three core CSF biomarkers for the biochemical diagnosis of $\mathrm{AD}$, including standardization and harmonization of (pre-) analytical procedures. One of the most important recommendations with a significant effect on pre-analytical variability is likely to be the implementation of the $A \beta_{1-42} / A \beta_{1-40}$ into the clinical diagnostic work-up. This is especially important since $A \beta_{1-42}$ has proven to be the earliest marker to reflect $\mathrm{AD}$ related pathological changes take place in the brain and the ratio show a higher concordance with amyloid pathology. At present, low CSF $A \beta_{1-42}$ 
concentration is an inclusion criterion for several clinical trials with potential disease-modifying drugs that target $\mathrm{AD}$ in its earliest (and even preclinical) stages. Hence, biomarkers reflecting the pathology targeted by specific clinical trials are essential for inclusion but also to monitor treatment effects. Early clinical detection is also likely to become more important as soon as disease-modifying pharmacological treatment for AD is available as medications that halt or prevent the disease are likely to be most effective at an early stage, when neurodegeneration has not become too severe. The validated core AD CSF biomarkers have an added value in the early and differential diagnosis of $\mathrm{AD}$ and related disorders, including mixed pathologies, atypical presentations of $\mathrm{AD}$, and in case of ambiguous dementia diagnosis.

\section{ACKNOWLEDGMENTS}

This research was funded in part by the University of Antwerp Research Fund; unrestrictive research grants from Janssen Pharmaceutica NV and ADx Neurosciences; the Flanders Impulse Program on Networks for Dementia Research (VIND); Flanders Innovation \& Entrepreneurship (VLAIO). The authors acknowledge the editorial assistance of Dr. Sara Valckx.

Authors' disclosures available online (https:// www.j-alz.com/manuscript-disclosures/17-0680r1).

\section{REFERENCES}

[1] Bier JC, Verschraegen J, Vandenberghe R, Guillaume B, Picard G, Otte G, Mormont E, Gilles C, Segers K, Sieben A, Thiery E, Ventura M, De Deyn P, Deryck O, Versijpt J, Salmon E, Engelborghs S, Ivanoiu A (2015) Clinical utility and applicability of biomarker-based diagnostic criteria for Alzheimer's disease: A BeDeCo survey. Acta Neurol Belg 115, 547-555.

[2] Engelborghs S, De Vreese K, Van de Casteele T, Vanderstichele H, Van Everbroeck B, Cras P, Martin JJ, Vanmechelen E, De Deyn PP (2008) Diagnostic performance of a CSF-biomarker panel in autopsy-confirmed dementia. Neurobiol Aging 29, 1143-1159.

[3] Brunnstrom H, Englund E (2009) Clinicopathological concordance in dementia diagnostics. Am J Geriatr Psychiatry 17, 664-670

[4] Le Bastard N, Martin JJ, Vanmechelen E, Vanderstichele H, De Deyn PP, Engelborghs S (2010) Added diagnostic value of CSF biomarkers in differential dementia diagnosis. Neurobiol Aging 31, 1867-1876.

[5] Niemantsverdriet E, Feyen BF, Le Bastard N, Martin JJ, Goeman J, De Deyn PP, Engelborghs S (2015) Overdiagnosing vascular dementia using structural brain imaging for dementia work-up. J Alzheimers Dis 45, 1039-1043.

[6] Sperling RA, Aisen PS, Beckett LA, Bennett DA, Craft S, Fagan AM, Iwatsubo T, Jack CR Jr, Kaye J, Montine
TJ, Park DC, Reiman EM, Rowe CC, Siemers E, Stern Y, Yaffe K, Carrillo MC, Thies B, Morrison-Bogorad M, Wagster MV, Phelps CH (2011) Toward defining the preclinical stages of Alzheimer's disease: Recommendations from the National Institute on Aging-Alzheimer's Association workgroups on diagnostic guidelines for Alzheimer's disease. Alzheimers Dement 7, 280-292.

[7] Sevigny J, Chiao P, Bussiere T, Weinreb PH, Williams L, Maier M, Dunstan R, Salloway S, Chen T, Ling Y, O'Gorman J, Qian F, Arastu M, Li M, Chollate S, Brennan MS, Quintero-Monzon O, Scannevin RH, Arnold HM, Engber T, Rhodes K, Ferrero J, Hang Y, Mikulskis A, Grimm J, Hock C, Nitsch RM, Sandrock A (2016) The antibody aducanumab reduces Abeta plaques in Alzheimer's disease. Nature 537, 50-56.

[8] Olsson B, Lautner R, Andreasson U, Ohrfelt A, Portelius E, Bjerke M, Holtta M, Rosen C, Olsson C, Strobel G, Wu E, Dakin K, Petzold M, Blennow K, Zetterberg H (2016) CSF and blood biomarkers for the diagnosis of Alzheimer's disease: A systematic review and meta-analysis. Lancet Neurol 15, 673-684.

[9] Mattsson N, Zetterberg H, Blennow K (2010) Lessons from multicenter studies on CSF biomarkers for Alzheimer's disease. Int J Alzheimers Dis 2010, 610613.

[10] Blennow K, Vanmechelen E, Hampel H (2001) CSF total tau, Abeta42 and phosphorylated tau protein as biomarkers for Alzheimer's disease. Mol Neurobiol 24, 87-97.

[11] Jack CR Jr, Bennett DA, Blennow K, Carrillo MC, Feldman HH, Frisoni GB, Hampel H, Jagust WJ, Johnson KA, Knopman DS, Petersen RC, Scheltens P, Sperling RA, Dubois B (2016) A/T/N: An unbiased descriptive classification scheme for Alzheimer disease biomarkers. Neurology 87, 539-547.

[12] Albert MS, DeKosky ST, Dickson D, Dubois B, Feldman HH, Fox NC, Gamst A, Holtzman DM, Jagust WJ, Petersen RC, Snyder PJ, Carrillo MC, Thies B, Phelps CH (2011) The diagnosis of mild cognitive impairment due to Alzheimer's disease: Recommendations from the National Institute on Aging-Alzheimer's Association workgroups on diagnostic guidelines for Alzheimer's disease. Alzheimers Dement 7, 270-279.

[13] McKhann GM, Knopman DS, Chertkow H, Hyman BT, Jack CR Jr, Kawas CH, Klunk WE, Koroshetz WJ, Manly JJ, Mayeux R, Mohs RC, Morris JC, Rossor MN, Scheltens P, Carrillo MC, Thies B, Weintraub S, Phelps $\mathrm{CH}$ (2011) The diagnosis of dementia due to Alzheimer's disease: Recommendations from the National Institute on Aging-Alzheimer's Association workgroups on diagnostic guidelines for Alzheimer's disease. Alzheimers Dement 7, 263-269.

[14] Dubois B, Feldman HH, Jacova C, Hampel H, Molinuevo JL, Blennow K, DeKosky ST, Gauthier S, Selkoe D, Bateman R, Cappa S, Crutch S, Engelborghs S, Frisoni GB, Fox NC, Galasko D, Habert MO, Jicha GA, Nordberg A, Pasquier F, Rabinovici G, Robert P, Rowe C, Salloway S, Sarazin M, Epelbaum S, de Souza LC, Vellas B, Visser PJ, Schneider L, Stern Y, Scheltens P, Cummings JL (2014) Advancing research diagnostic criteria for Alzheimer's disease: The IWG-2 criteria. Lancet Neurol 13, 614-629.

[15] Hansson O, Zetterberg H, Buchhave P, Londos E, Blennow K, Minthon L (2006) Association between CSF biomarkers and incipient Alzheimer's disease in patients with mild cognitive impairment: A follow-up study. Lancet Neurol 5, 228-234. 
[16] Mattsson N, Zetterberg H, Hansson O, Andreasen N, Parnetti L, Jonsson M, Herukka SK, van der Flier WM, Blankenstein MA, Ewers M, Rich K, Kaiser E, Verbeek M, Tsolaki M, Mulugeta E, Rosen E, Aarsland D, Visser PJ, Schroder J, Marcusson J, de Leon M, Hampel H, Scheltens P, Pirttila T, Wallin A, Jonhagen ME, Minthon L, Winblad B, Blennow K (2009) CSF biomarkers and incipient Alzheimer disease in patients with mild cognitive impairment. JAMA 302, 385-393.

[17] Niemantsverdriet E, Valckx S, Bjerke M, Engelborghs S (2017) Alzheimer's disease CSF biomarkers: Clinical indications and rational use. Acta Neurol Belg 117, 591-602.

[18] Engelborghs S, Le Bastard N (2012) The role of CSF biomarkers in the diagnostic work-up of mixed vasculardegenerative dementia. J Neurol Sci 322, 197-199.

[19] Engelborghs S (2013) Clinical indications for analysis of Alzheimer's disease CSF biomarkers. Rev Neurol (Paris) 169, 709-714.

[20] Somers C, Struyfs H, Goossens J, Niemantsverdriet E, Luyckx J, De Roeck N, De Roeck E, De Vil B, Cras P, Martin JJ, De Deyn PP, Bjerke M, Engelborghs S (2016) A decade of cerebrospinal fluid biomarkers for Alzheimer's disease in Belgium. J Alzheimers Dis 54, 383-395.

[21] Lleo A, Cavedo E, Parnetti L, Vanderstichele H, Herukka SK, Andreasen N, Ghidoni R, Lewczuk P, Jeromin A, Winblad B, Tsolaki M, Mroczko B, Visser PJ, Santana I, Svenningsson P, Blennow K, Aarsland D, Molinuevo JL, Zetterberg H, Mollenhauer B (2015) Cerebrospinal fluid biomarkers in trials for Alzheimer and Parkinson diseases. Nat Rev Neurol 11, 41-55.

[22] Simonsen AH, Herukka SK, Andreasen N, Baldeiras I, Bjerke M, Blennow K, Engelborghs S, Frisoni GB, Gabryelewicz T, Galluzzi S, Handels R, Kramberger MG, Kulczynska A, Molinuevo JL, Mroczko B, Nordberg A, Oliveira CR, Otto M, Rinne JO, Rot U, Saka E, Soininen H, Struyfs H, Suardi S, Visser PJ, Winblad B, Zetterberg H, Waldemar G (2017) Recommendations for CSF $\mathrm{AD}$ biomarkers in the diagnostic evaluation of dementia. Alzheimers Dement 13, 274-284.

[23] Herukka SK, Simonsen AH, Andreasen N, Baldeiras I, Bjerke M, Blennow K, Engelborghs S, Frisoni GB, Gabryelewicz T, Galluzzi S, Handels R, Kramberger MG, Kulczynska A, Molinuevo JL, Mroczko B, Nordberg A, Oliveira CR, Otto M, Rinne JO, Rot U, Saka E, Soininen H, Struyfs H, Suardi S, Visser PJ, Winblad B, Zetterberg H, Waldemar G (2017) Recommendations for cerebrospinal fluid Alzheimer's disease biomarkers in the diagnostic evaluation of mild cognitive impairment. Alzheimers Dement 13, 285-295.

[24] Le Bastard N, Aerts L, Leurs J, Blomme W, De Deyn PP, Engelborghs S (2009) No correlation between time-linked plasma and CSF Abeta levels. Neurochem Int 55, 820-825.

[25] Le Bastard N, Leurs J, Blomme W, De Deyn PP, Engelborghs S (2010) Plasma amyloid-beta forms in Alzheimer's disease and non-Alzheimer's disease patients. J Alzheimers Dis 21, 291-301.

[26] De Vos A, Jacobs D, Struyfs H, Fransen E, Andersson K, Portelius E, Andreasson U, De Surgeloose D, Hernalsteen D, Sleegers K, Robberecht C, Van Broeckhoven C, Zetterberg H, Blennow K, Engelborghs S, Vanmechelen E (2015) $\mathrm{C}$-terminal neurogranin is increased in cerebrospinal fluid but unchanged in plasma in Alzheimer's disease. Alzheimers Dement 11, 1461-1469.

[27] Engelborghs S, Sleegers K, Cras P, Brouwers N, Serneels $\mathrm{S}$, De Leenheir E, Martin JJ, Vanmechelen E, Van
Broeckhoven C, De Deyn PP (2007) No association of CSF biomarkers with APOEepsilon4, plaque and tangle burden in definite Alzheimer's disease. Brain 130, 2320-2326.

[28] Strozyk D, Blennow K, White LR, Launer LJ (2003) CSF Abeta 42 levels correlate with amyloid-neuropathology in a population-based autopsy study. Neurology 60, 652-656.

[29] Toledo JB, Bjerke M, Da X, Landau SM, Foster NL, Jagust W, Jack C Jr, Weiner M, Davatzikos C, Shaw LM, Trojanowski JQ, Alzheimer's Disease Neuroimaging Initiative (2015) Nonlinear association between cerebrospinal fluid and Florbetapir F-18 beta-amyloid measures across the spectrum of Alzheimer disease. JAMA Neurol 72, 571-581.

[30] Leuzy A, Chiotis K, Hasselbalch SG, Rinne JO, de Mendonca A, Otto M, Lleo A, Castelo-Branco M, Santana I, Johansson J, Anderl-Straub S, von Arnim CA, Beer A, Blesa R, Fortea J, Herukka SK, Portelius E, Pannee J, Zetterberg H, Blennow K, Nordberg A (2016) Pittsburgh compound B imaging and cerebrospinal fluid amyloid-beta in a multicentre European memory clinic study. Brain 139, 2540-2553.

[31] Niemantsverdriet E, Ottoy J, Somers C, De Roeck E, Struyfs H, Soetewey F, Verhaeghe J, Van den Bossche T, Van Mossevelde S, Goeman J, De Deyn PP, Marien P, Versijpt J, Sleegers K, Van Broeckhoven C, Wyffels L, Albert A, Ceyssens S, Stroobants S, Staelens S, Bjerke M, Engelborghs S (2017) The cerebrospinal fluid Abeta1-42/Abeta1-40 ratio improves concordance with amyloid-PET for diagnosing Alzheimer's disease in a clinical setting. J Alzheimers Dis 60, 561-576.

[32] Wallin A, Nordlund A, Jonsson M, Lind K, Edman A, Gothlin M, Stalhammar J, Eckerstrom M, Kern S, Borjesson-Hanson A, Carlsson M, Olsson E, Zetterberg H, Blennow K, Svensson J, Ohrfelt A, Bjerke M, Rolstad S, Eckerstrom C (2016) The Gothenburg MCI study: Design and distribution of Alzheimer's disease and subcortical vascular disease diagnoses from baseline to 6-year follow-up. J Cereb Blood Flow Metab 36, 114-131.

[33] Buchhave P, Minthon L, Zetterberg H, Wallin AK, Blennow K, Hansson O (2012) Cerebrospinal fluid levels of betaamyloid 1-42, but not of tau, are fully changed already 5 to 10 years before the onset of Alzheimer dementia. Arch Gen Psychiatry 69, 98-106.

[34] Koopman K, Le Bastard N, Martin JJ, Nagels G, De Deyn PP, Engelborghs S (2009) Improved discrimination of autopsy-confirmed Alzheimer's disease (AD) from nonAD dementias using CSF P-tau(181P). Neurochem Int 55, 214-218.

[35] Struyfs H, Niemantsverdriet E, Goossens J, Fransen E, Martin JJ, De Deyn PP, Engelborghs S (2015) Cerebrospinal fluid P-Tau181P: Biomarker for improved differential dementia diagnosis. Front Neurol 6, 138.

[36] Bjerke M, Andreasson U, Rolstad S, Nordlund A, Lind K, Zetterberg H, Edman A, Blennow K, Wallin A (2009) Subcortical vascular dementia biomarker pattern in mild cognitive impairment. Dement Geriatr Cogn Disord 28, 348-356.

[37] Bjerke M, Zetterberg H, Edman A, Blennow K, Wallin A, Andreasson U (2011) Cerebrospinal fluid matrix metalloproteinases and tissue inhibitor of metalloproteinases in combination with subcortical and cortical biomarkers in vascular dementia and Alzheimer's disease. J Alzheimers Dis 27, 665-676.

[38] Slaets S, Le Bastard N, Theuns J, Sleegers K, Verstraeten A, De Leenheir E, Luyckx J, Martin JJ, Van Broeckhoven C, Engelborghs S (2013) Amyloid pathology influences 
abeta1-42 cerebrospinal fluid levels in dementia with lewy bodies. J Alzheimers Dis 35, 137-146.

[39] Dorey A, Tholance Y, Vighetto A, Perret-Liaudet A, Lachman I, Krolak-Salmon P, Wagner U, Struyfs H, De Deyn PP, El-Moualij B, Zorzi W, Meyronet D, Streichenberger N, Engelborghs S, Kovacs GG, Quadrio I (2015) Association of cerebrospinal fluid prion protein levels and the distinction between Alzheimer disease and Creutzfeldt-Jakob disease. JAMA Neurol 72, 267-275.

[40] Goossens J, Bjerke M, Struyfs H, Niemantsverdriet E, Somers C, Van den Bossche T, Van Mossevelde S, De Vil B, Sieben A, Martin JJ, Cras P, Goeman J, De Deyn PP, Van Broeckhoven C, van der Zee J, Engelborghs S (2017) No added diagnostic value of non-phosphorylated tau fraction (p-taurel) in CSF as a biomarker for differential dementia diagnosis. Alzheimers Res Ther 9, 49.

[41] Kanai M, Matsubara E, Isoe K, Urakami K, Nakashima K, Arai H, Sasaki H, Abe K, Iwatsubo T, Kosaka T, Watanabe M, Tomidokoro Y, Shizuka M, Mizushima K, Nakamura T, Igeta Y, Ikeda Y, Amari M, Kawarabayashi T, Ishiguro K, Harigaya Y, Wakabayashi K, Okamoto K, Hirai S, Shoji M (1998) Longitudinal study of cerebrospinal fluid levels of tau, A beta1-40, and A beta1-42(43) in Alzheimer's disease: A study in Japan. Ann Neurol 44, 17-26.

[42] Shoji M, Matsubara E, Kanai M, Watanabe M, Nakamura T, Tomidokoro Y, Shizuka M, Wakabayashi K, Igeta Y, Ikeda Y, Mizushima K, Amari M, Ishiguro K, Kawarabayashi T, Harigaya Y, Okamoto K, Hirai S (1998) Combination assay of CSF tau, A beta 1-40 and A beta 1-42(43) as a biochemical marker of Alzheimer's disease. J Neurol Sci 158, 134-140.

[43] Palmqvist S, Mattsson N, Hansson O, Alzheimer's Disease Neuroimaging Initiative (2016) Cerebrospinal fluid analysis detects cerebral amyloid-beta accumulation earlier than positron emission tomography. Brain 139, 1226-1236.

[44] Janelidze S, Zetterberg H, Mattsson N, Palmqvist S, Vanderstichele H, Lindberg O, van Westen D, Stomrud E, Minthon L, Blennow K, Swedish BioFINDER study group, Hansson O (2016) CSF Abeta42/Abeta40 and Abeta42/Abeta38 ratios: Better diagnostic markers of Alzheimer disease. Ann Clin Transl Neurol 3, 154-165.

[45] Lewczuk P, Matzen A, Blennow K, Parnetti L, Molinuevo JL, Eusebi P, Kornhuber J, Morris JC, Fagan AM (2017) Cerebrospinal fluid Abeta42/40 corresponds better than Abeta42 to amyloid PET in Alzheimer's disease. J Alzheimers Dis 55, 813-822.

[46] Janelidze S, Pannee J, Mikulskis A, Chiao P, Zetterberg H, Blennow K, Hansson O (2017) Concordance between different amyloid immunoassays and visual amyloid positron emission tomographic assessment. JAMA Neurol 74, 14921501.

[47] Struyfs H, Van Broeck B, Timmers M, Fransen E, Sleegers K, Van Broeckhoven C, De Deyn PP, Streffer JR, Mercken M, Engelborghs S (2015) Diagnostic accuracy of cerebrospinal fluid amyloid-beta isoforms for early and differential dementia diagnosis. J Alzheimers Dis 45, 813-822.

[48] Slaets S, Le Bastard N, Martin JJ, Sleegers K, Van Broeckhoven C, De Deyn PP, Engelborghs S (2013) Cerebrospinal fluid Abeta1-40 improves differential dementia diagnosis in patients with intermediate P-tau181P levels. J Alzheimers Dis 36, 759-767.

[49] Dumurgier J, Schraen S, Gabelle A, Vercruysse O, Bombois S, Laplanche JL, Peoc'h K, Sablonniere B, Kastanenka KV, Delaby C, Pasquier F, Touchon J, Hugon J, Paquet C, Lehmann S (2015) Cerebrospinal fluid amyloid-beta $42 / 40$ ratio in clinical setting of memory centers: A multicentric study. Alzheimers Res Ther 7, 30.

[50] Hansson O, Zetterberg H, Buchhave P, Andreasson U, Londos E, Minthon L, Blennow K (2007) Prediction of Alzheimer's disease using the CSF Abeta42/Abeta40 ratio in patients with mild cognitive impairment. Dement Geriatr Cogn Disord 23, 316-320.

[51] Pijnenburg YA, Verwey NA, van der Flier WM, Scheltens P, Teunissen CE (2015) Discriminative and prognostic potential of cerebrospinal fluid phosphoTau/tau ratio and neurofilaments for frontotemporal dementia subtypes. Alzheimers Dement (Amst) 1, 505-512.

[52] Lewczuk P, Lelental N, Lachmann I, Holzer M, Flach $\mathrm{K}$, Brandner S, Engelborghs S, Teunissen CE, Zetterberg $\mathrm{H}$, Molinuevo JL, Mroczko B, Blennow K, Popp J, Parnetti L, Chiasserini D, Perret-Liaudet A, Spitzer P, Maler JM, Kornhuber J (2017) Non-phosphorylated tau as a potential biomarker of Alzheimer's disease: Analytical and diagnostic characterization. J Alzheimers Dis $\mathbf{5 5}$, 159-170.

[53] Brinkmalm G, Brinkmalm A, Bourgeois P, Persson R, Hansson O, Portelius E, Mercken M, Andreasson U, Parent S, Lipari F, Ohrfelt A, Bjerke M, Minthon L, Zetterberg H, Blennow K, Nutu M (2013) Soluble amyloid precursor protein alpha and beta in CSF in Alzheimer's disease. Brain Res 1513, 117-126.

[54] Somers C, Goossens J, Engelborghs S, Bjerke M (2017) Selecting Abeta isoforms for an Alzheimer's disease cerebrospinal fluid biomarker panel. Biomark Med 11, 169-178.

[55] Bjerke M, Jonsson M, Nordlund A, Eckerstrom C, Blennow K, Zetterberg H, Pantoni L, Inzitari D, Schmidt R, Wallin A (2014) Cerebrovascular biomarker profile is related to white matter disease and ventricular dilation in a LADIS substudy. Dement Geriatr Cogn Dis Extra 4, 385-394.

[56] Le Bastard N, Van Buggenhout M, De Leenheir E, Martin JJ, De Deyn PP, Engelborghs S (2007) LOW specificity limits the use of the cerebrospinal fluid Abeta1-42/P-TAU181P ratio to discriminate Alzheimer's disease from vascular dementia. J Gerontol A Biol Sci Med Sci 62, 923-924; author reply 924-925.

[57] Thorsell A, Bjerke M, Gobom J, Brunhage E, Vanmechelen E, Andreasen N, Hansson O, Minthon L, Zetterberg H, Blennow K (2010) Neurogranin in cerebrospinal fluid as a marker of synaptic degeneration in Alzheimer's disease. Brain Res 1362, 13-22.

[58] Wallin A, Ohrfelt A, Bjerke M (2012) Characteristic clinical presentation and CSF biomarker pattern in cerebral small vessel disease. J Neurol Sci 322, 192-196.

[59] Rosenberg GA, Bjerke M, Wallin A (2014) Multimodal markers of inflammation in the subcortical ischemic vascular disease type of vascular cognitive impairment. Stroke 45, 1531-1538.

[60] Wallin A, Kapaki E, Boban M, Engelborghs S, Hermann DM, Huisa B, Jonsson M, Kramberger MG, Lossi L, Malojcic B, Mehrabian S, Merighi A, Mukaetova-Ladinska EB, Paraskevas GP, Popescu BO, Ravid R, Traykov L, Tsivgoulis G, Weinstein G, Korczyn A, Bjerke M, Rosenberg G (2017) Biochemical markers in vascular cognitive impairment associated with subcortical small vessel disease - A consensus report. BMC Neurol 17, 102.

[61] Jonsson M, Zetterberg H, Rolstad S, Edman A, Gouw AA, Bjerke M, Lind K, Blennow K, Pantoni L, Inzitari D, Wallin A (2012) Low cerebrospinal fluid sulfatide predicts progression of white matter lesions: The LADIS study. Dement Geriatr Cogn Disord 34, 61-67. 
[62] Wallin A, Nordlund A, Jonsson M, Blennow K, Zetterberg H, Ohrfelt A, Stalhammar J, Eckerstrom M, Carlsson M, Olsson E, Gothlin M, Svensson J, Rolstad S, Eckerstrom C, Bjerke M (2016) Alzheimer's disease-subcortical vascular disease spectrum in a hospital-based setting: Overview of results from the Gothenburg MCI and dementia studies. J Cereb Blood Flow Metab 36, 95-113.

[63] Hjalmarsson C, Bjerke M, Andersson B, Blennow K, Zetterberg H, Aberg ND, Olsson B, Eckerstrom C, Bokemark L, Wallin A (2014) Neuronal and glia-related biomarkers in cerebrospinal fluid of patients with acute ischemic stroke. J Cent Nerv Syst Dis 6, 51-58.

[64] Zetterberg H, Skillback T, Mattsson N, Trojanowski JQ, Portelius E, Shaw LM, Weiner MW, Blennow K, Alzheimer's Disease Neuroimaging Initiative (2016) Association of cerebrospinal fluid neurofilament light concentration with Alzheimer disease progression. JAMA Neurol 73, 60-67.

[65] Sieben A, Van Langenhove T, Engelborghs S, Martin JJ, Boon P, Cras P, De Deyn PP, Santens P, Van Broeckhoven C, Cruts M (2012) The genetics and neuropathology of frontotemporal lobar degeneration. Acta Neuropathol 124, 353-372.

[66] Goossens J, Vanmechelen E, Trojanowski JQ, Lee VM, Van Broeckhoven C, van der Zee J, Engelborghs S (2015) TDP-43 as a possible biomarker for frontotemporal lobar degeneration: A systematic review of existing antibodies. Acta Neuropathol Commun 3, 15.

[67] Sleegers K, Brouwers N, Van Damme P, Engelborghs S, Gijselinck I, van der Zee J, Peeters K, Mattheijssens M, Cruts M, Vandenberghe R, De Deyn PP, Robberecht W, Van Broeckhoven C (2009) Serum biomarker for progranulinassociated frontotemporal lobar degeneration. Ann Neurol 65, 603-609.

[68] Ghidoni R, Benussi L, Glionna M, Franzoni M, Binetti G (2008) Low plasma progranulin levels predict progranulin mutations in frontotemporal lobar degeneration. Neurology 71, 1235-1239.

[69] Simonsen AH, Kuiperij B, El-Agnaf OM, Engelborghs S, Herukka SK, Parnetti L, Rektorova I, Vanmechelen E, Kapaki E, Verbeek M, Mollenhauer B (2016) The utility of alpha-synuclein as biofluid marker in neurodegenerative diseases: A systematic review of the literature. Biomark Med 10, 19-34.

[70] Kruse N, Persson S, Alcolea D, Bahl JM, Baldeiras I, Capello E, Chiasserini D, Bocchio Chiavetto L, Emersic A, Engelborghs S, Eren E, Fladby T, Frisoni G, GarciaAyllon MS, Genc S, Gkatzima O, Heegaard NH, Janeiro AM, Kovacech B, Kuiperij HB, Leitao MJ, Lleo A, Martins M, Matos M, Mollergard HM, Nobili F, Ohrfelt A, Parnetti L, de Oliveira CR, Rot U, Saez-Valero J, Struyfs H, Tanassi JT, Taylor P, Tsolaki M, Vanmechelen E, Verbeek MM, Zilka N, Blennow K, Zetterberg H, Mollenhauer B (2015) Validation of a quantitative cerebrospinal fluid alphasynuclein assay in a European-wide interlaboratory study. Neurobiol Aging 36, 2587-2596.

[71] Slaets S, Vanmechelen E, Le Bastard N, Decraemer H, Vandijck M, Martin JJ, De Deyn PP, Engelborghs S (2014) Increased CSF alpha-synuclein levels in Alzheimer's disease: Correlation with tau levels. Alzheimers Dement 10, S290-S298.

[72] Zerr I, Bodemer M, Gefeller O, Otto M, Poser S, Wiltfang J, Windl O, Kretzschmar HA, Weber T (1998) Detection of 143-3 protein in the cerebrospinal fluid supports the diagnosis of Creutzfeldt-Jakob disease. Ann Neurol 43, 32-40.
[73] Van Everbroeck B, Quoilin S, Boons J, Martin JJ, Cras P (2003) A prospective study of CSF markers in 250 patients with possible Creutzfeldt-Jakob disease. J Neurol Neurosurg Psychiatry 74, 1210-1214.

[74] Bjerke M, Portelius E, Minthon L, Wallin A, Anckarsater $\mathrm{H}$, Anckarsater R, Andreasen N, Zetterberg H, Andreasson U, Blennow K (2010) Confounding factors influencing amyloid Beta concentration in cerebrospinal fluid. Int $J$ Alzheimers Dis 2010, 986310.

[75] Le Bastard N, De Deyn PP, Engelborghs S (2015) Importance and impact of preanalytical variables on Alzheimer disease biomarker concentrations in cerebrospinal fluid. Clin Chem 61, 734-743.

[76] Willemse E, van Uffelen K, Brix B, Engelborghs S, Vanderstichele H, Teunissen C (2017) How to handle adsorption of cerebrospinal fluid amyloid-beta (1-42) in laboratory practice? Identifying problematic handlings and resolving the issue by use of the Abeta42/Abeta40 ratio. Alzheimers Dement 13, 885-892.

[77] Lewczuk P, Beck G, Esselmann H, Bruckmoser R, Zimmermann R, Fiszer M, Bibl M, Maler JM, Kornhuber J, Wiltfang J (2006) Effect of sample collection tubes on cerebrospinal fluid concentrations of tau proteins and amyloid beta peptides. Clin Chem 52, 332-334.

[78] Niemantsverdriet E, Goossens J, Struyfs H, Martin JJ, Goeman J, De Deyn PP, Vanderstichele H, Engelborghs S (2016) Diagnostic impact of cerebrospinal fluid biomarker (pre-)analytical variability in Alzheimer's disease. J Alzheimers Dis 51, 97-106.

[79] Bjerke M, Andreasson U, Kuhlmann J, Portelius E, Pannee J, Lewczuk P, Umek RM, Vanmechelen E, Vanderstichele H, Stoops E, Lewis J, Vandijck M, Kostanjevecki V, Jeromin A, Salamone SJ, Schmidt O, Matzen A, Madin K, Eichenlaub U, Bittner T, Shaw LM, Zegers I, Zetterberg H, Blennow K (2016) Assessing the commutability of reference material formats for the harmonization of amyloid-beta measurements. Clin Chem Lab Med 54, 1177-1191.

[80] Mattsson N, Zegers I, Andreasson U, Bjerke M, Blankenstein MA, Bowser R, Carrillo MC, Gobom J, Heath T, Jenkins R, Jeromin A, Kaplow J, Kidd D, Laterza OF, Lockhart A, Lunn MP, Martone RL, Mills K, Pannee J, Ratcliffe M, Shaw LM, Simon AJ, Soares H, Teunissen CE, Verbeek MM, Umek RM, Vanderstichele H, Zetterberg H, Blennow K, Portelius E (2012) Reference measurement procedures for Alzheimer's disease cerebrospinal fluid biomarkers: Definitions and approaches with focus on amyloid beta42. Biomark Med 6, 409-417.

[81] Kuhlmann J, Andreasson U, Pannee J, Bjerke M, Portelius E, Leinenbach A, Bittner T, Korecka M, Jenkins RG, Vanderstichele H, Stoops E, Lewczuk P, Shaw LM, Zegers I, Schimmel H, Zetterberg H, Blennow K, IFCC Working Group on Standardization of CSF proteins (WG-CSF) (2017) CSF Abeta1-42 - an excellent but complicated Alzheimer's biomarker - a route to standardisation. Clin Chim Acta 467, 27-33.

[82] Mattsson N, Andreasson U, Persson S, Arai H, Batish SD, Bernardini S, Bocchio-Chiavetto L, Blankenstein MA, Carrillo MC, Chalbot S, Coart E, Chiasserini D, Cutler N, Dahlfors G, Duller S, Fagan AM, Forlenza O, Frisoni GB, Galasko D, Galimberti D, Hampel H, Handberg A, Heneka MT, Herskovits AZ, Herukka SK, Holtzman DM, Humpel C, Hyman BT, Iqbal K, Jucker M, Kaeser SA, Kaiser E, Kapaki E, Kidd D, Klivenyi P, Knudsen CS, Kummer MP, Lui J, Llado A, Lewczuk P, Li QX, Martins R, Masters C, McAuliffe J, Mercken M, Moghekar A, Molinuevo JL, 
Montine TJ, Nowatzke W, O’Brien R, Otto M, Paraskevas GP, Parnetti L, Petersen RC, Prvulovic D, de Reus HP, Rissman RA, Scarpini E, Stefani A, Soininen H, Schroder J, Shaw LM, Skinningsrud A, Skrogstad B, Spreer A, Talib L, Teunissen C, Trojanowski JQ, Tumani H, Umek RM, Van Broeck B, Vanderstichele H, Vecsei L, Verbeek MM, Windisch M, Zhang J, Zetterberg H, Blennow K (2011) The Alzheimer's Association external quality control program for cerebrospinal fluid biomarkers. Alzheimers Dement 7, 386-395 e386.

[83] Molinuevo JL, Blennow K, Dubois B, Engelborghs S, Lewczuk P, Perret-Liaudet A, Teunissen CE, Parnetti L (2014) The clinical use of cerebrospinal fluid biomarker testing for Alzheimer's disease diagnosis: A consensus paper from the Alzheimer's Biomarkers Standardization Initiative. Alzheimers Dement 10, 808-817.

[84] Vanderstichele H, Bibl M, Engelborghs S, Le Bastard N, Lewczuk P, Molinuevo JL, Parnetti L, Perret-Liaudet A, Shaw LM, Teunissen C, Wouters D, Blennow K (2012) Standardization of preanalytical aspects of cerebrospinal fluid biomarker testing for Alzheimer's disease diagnosis: A consensus paper from the Alzheimer's Biomarkers Standardization Initiative. Alzheimers Dement 8, 65-73. 